\title{
How a Proper Performance Related Reward System Can Contribute to Work Performance Excellence
}

\author{
Sara Indileni Hamukwaya, Rashad Yazdanifard \\ Centre of Post Graduates Studies, Limkokwing University of Creative Technology, Cyberjaya, Malaysia \\ Email: sarahamukwaya@yahoo.com, rashadyazdanifard@yahoo.com
}

Received 6 May 2014; revised 10 June 2014; accepted 1 July 2014

Copyright (C) 2014 by authors and Scientific Research Publishing Inc.

This work is licensed under the Creative Commons Attribution International License (CC BY). http://creativecommons.org/licenses/by/4.0/ c) (i) Open Access

\begin{abstract}
Performance related rewards came in picture in recent years for so many reasons. That includes rewards as motivation for employees to excel, reduce employer-employee conflicts and ensure fair reward treatments. This also includes a response to a call of worker's dissatisfaction at work, poor work performance, negative attitudes, lack of motivation and agency problems. These "ills" will only be "cured" if there are proper performance measures in place. This study examined how a proper performance related reward system can be used as a tool to enhance work performance. The study include different performance related reward systems that may be embraced by management to foster work performance, what performance appraisal measures need to be put in place and the relationship between performance related reward systems and work performance. The benefits of embracing the Performance based rewards are also discussed.
\end{abstract}

\section{Keywords}

Performance-Related Reward System, Work Performance, Performance Appraisal

\section{Introduction}

It is the task of every organisation to enhance its organisational performance. One of the best ways to put forth this is to put in place a proper performance based reward system. Performance as outlined by Luccier [1] is based on three factors: That is ability, motivation and resources. This implies that for greater work enhancement, all the aforesaid factors must be high. In other words, organisational rewards must be linked towork performance to achieve better or improved organizational results provided that the organisation have enough resources and employees are qualified or trained to carry out their jobs. According to Mclagan and Nel as cited in Tsai, 
Chou \& Chen [2], rewards are a crucial lever to shape employees toward any desired goal of the organisation. Desired goals stated here can be greater returns on investments, profits, improved customer services, gaining greater market shares, competitive advantage and all that contribute to the success of any organisation. Milne as cited in Tsun, Shang and I-Jan [3] and Gross, Elhayney, Friedman and Buetow [4] provided that organisational rewards are some of the mechanisms that can be used to stimulate knowledge sharing, quality of work, motivate to supply efforts (Barth, Bratsberg, Haegeland, Raaum, [5]) as well as work performance among organisational members. This implies that if work members and work teams are rewarded according to their performance, they will make significant contributions to their organisations. It is thus of fundamental importance for every organisation to decide how best to reward its employees and on what basis will they be rewarded. The questions of how, why and when to enhance work performance excellence are tackled in this study.

\section{Performance Related Reward Systems}

Manson and Watts [6] provides that rewards matters in organisations. As outlined by (Zhou, Zhang and Sanchez [7]) and (Canos-Daros [8]) rewards come in many forms such as base salary increases, performance bonuses, coupons, allowances, acquisitiveness, cash prices, promotions, team incentives, retirement, security benefits, and so on. A performance related reward is defined by Lazear (as cited by Irs and Turk [9]) as a form of reward whereby employees are compensated according to their performance. On the other hand, Dransfield as cited in Irs and Turk [9] provides that performance related systems use performance and competence as basis to decide the level of increments as well as the rate of progress through a salary band. It is however of significant importance to note the pros and cons that are associated with this reward system as outlined by Irs and Turk [9].

\subsection{Pros}

- Recruitment and retention of qualified and competent personnel

- Motivation of employees and their work teams

- Raises willingness to take on challenging tasks

- Save money

- Efficient administration

- Attainment of organisational goals and objectives through work commitment

\subsection{Cons}

- There are issues related to performance appraisal

- Unrewarded tasks may be neglected

- Demotivation of unrewarded or low rewarded employees

- Competition between employees instead of corporation

- Bias and lack of openness

- High cost

Provided the above advantages and disadvantages of performance based rewards, it is of general phenomenon to conclude that an individual need to be rewarded for him or her perform outstandingly. As outlined by IRS and Turk [9], it is believed that high quality workers are attracted to an organisation where they feel their ability, efforts and competencies are rewarded. Hence, their salary level affects their choice to work in their respective professions. Mao, Son and Han [10] provide that the implementation of the work performance systems contributes to organisational performance despite facts that these systems may be difficult to implement. They further provide that managers hiked up in this difficulties require a major understanding on how to implement as well as monitor the aforesaid systems.

\section{Non-Monetary Rewards}

More as to say, by incorporating Fredrick Herzberg's theory as embraced by (Crumpton [11]), all employees need is not only monetary but also acknowledgment, through non-monetary rewards. Workers need to be praised as well as guaranteed an opportunity for advancement. Markova and Ford [12], provide that incorporating non-monetary rewards in compensation systems can maintain job interest as well as improve the cooperation of workers. Crumpton [11] further pointed out that managers and supervisors may give positive feedback by re- 
warding good behaviours as well as publicly recognise the deserving employees. These rewards are less expensive for organisations rather than monetary rewards.

\subsection{Joint Reward Systems}

Gupta et al. (as cited in Tsun et al., [3]) are of the opinion that organisations may not only reward individual efforts but also reward joint efforts across functions. An example could be rewarding Research and Development teams as well as marketing groups that are responsible for the success or failures of new products. Tsun et al., [3] further provides that the conventional practices in measuring joint reward systems are based on the degree of collaboration across functions like the aforesaid Research and Development as well as marketing which assumes all the departments are evaluated accordingly in successful commercialisation of new products. Joint Reward systems results into consistent, yet positive results in estimating knowledge sharing and performance.

Tsun et al., [3] further stresses that knowledge sharing is the important aspect among work members, and it is thus a duty of management to foster knowledge sharing in their organisations. Moreover, formal reward systems based on knowledge sharing behaviours collective efforts, team based and companywide incentives and informal reward systems based on procedural fairness and trust are all conducive for knowledge sharing which also contributes to work performance. This is also supported by Zhou et al. [7] who stipulate that knowledge sharing is the fuel that powers innovation in firms. Again from the knowledge perspective as outlined by Van der Bij et al., and Song et al., (as cited in Tsai, et al., [2]), a firm's performance is enhanced when employees are highly rewarded. The rewards can influence their behaviours leading to high levels of knowledge application. Moreover, Rack, Ellwart, Hertel and Konrad [13], and Bamberger and Levi [14] provides that team based rewards increase efforts and performance of team members who are confident that they will benefit from the incentive scheme. Team based rewards stress organisational goals and foster commitment to the team such as a personal responsibility for work process, thereby enhancing work performance.

\subsection{Extrinsic and Intrinsic Rewards}

Baptiste [15], is of the saying that, employees strongly commit to an organisation for extrinsic as well as intrinsic rewards. Such commitment is viewed as an employees' positive engagement in their work, thereby attaining organisational goals. Zhou, et al., [7] in their recent study conducted in China referred to the two as utilitarianism (being extrinsic rewards and romantism as (intrinsic rewards). As cited in Zhou et al., [7], Winson and Baker, and Edwards referred to extrinsic incentives as monetary rewards aimed at motivating innovative behaviour of performance, whilst the latter as cited by Deci and Ryan, Amabile, Hennesey and Amabile in Zhou et al., [7] views creativity as self-motivated psychological behaviour driven by intrinsic spiritual rewards.

To justify the above, Zhou et al., [7] points out that tangible extrinsic reward are necessary to encourage innovative behaviour. On the other hand, intrinsic rewards with an emphasis on innovation orientation, flexible empowerment, recognition, learning support and the comprehensive development of human capital have a significant effect on promoting work performance. Markova and Ford [12], coined that knowledge workers value rewards that value their interests. These workers appear to locate more time to their work activities which corresponds to better supervisory ratings on work performance. Zhou et al., [7] are of the opinion that both extrinsic and intrinsic rewards shall be inclusive of each other and yet complementary when used as systems to enhance work performance. When the main effects of intrinsic motivation approach are fixed, the extrinsic reward approach can exploit a positive moderation to reinforce the positive impact of intrinsic motivations on employee creativity which enhance work performance excellence.

\section{Work Performance}

Work performance is defined by Campbel, (as cited in Koopmans, Bernards, Hilderbrandt, Schaufeli, De Vet and Der Beek [16]) as "behaviours or actions that are relevant to the goals of the organisation". On the other hand, Viswesvaran and Ones, (as cited in Koopmans et al., [16]) referred to work performance as "scalable actions, behaviours and outcomes that employees engage in or bring about that are linked with and contribute to organisational goals”.

Tsun, et al., [3] stresses how organisations have been scrambling for efforts to stimulate, facilitate as well as utilize their knowledge in order to gain competitive advantages. Several studies have reported that one of the major determinants of worker's rewards is performance (Barkema and Gomez-Meija), as cited in Ou and Wang 
[17]. On the other hand, Yilmaz and Chatterjee, (as cited in Ou and Wang [17]) and Silveira, Snider and Balakrishnan [18] are of the opinion that if rewards are closely tied to key performance measures, employees will perform above minimum expectations to maximise those performance measures and consequently maximise their pay level, Wiley [19] thereby maximizing organisation success.

\section{Performance Appraisal}

Based on existing research, it appears that what organisations and managers need to do is to encourage work performance by explicitly measuring and rewarding good performance through performance appraisal process [20]. Performance related rewards needs proper checks and balances. Schimdt, Trittel and Muller [21] referred to performance appraisal as the system used by superiors to assess or evaluate employees work performance. Criteria used are measurable and objectifiable. Prowse and Prowse [22] provide that the key objective for performance appraisal is to provide feedback to employees, thereby increasing motivation, clarifying goals as well as achieve long term individual performance, thus enhancing work performance. Human resource departments would however need to put measures in place the following measures as outlined by Lussier [1]:

1. Critical incidence file, which involves a manager keeping a written record of positive and negative performance of employees.

2. Management by objectives (MBO), whereby managers and employees jointly set objectives for the employees, evaluate results accordingly and reward as per evaluated performance. Managers may be at time be required to write reports on the performance of their employees.

3. Behaviourally Anchored Rating Scale (BARS) — This involves combining the rating scale and the critical incidents file. As Lussier put it, this is the more objective as well accurate method of performance appraisal. Rather than having ratings of excellent, good, average and poor, the form has several statements which tackle employee's performance.

4. Rating scale, this is a checklist on which a manager or superior evaluate the employee's quality and quantity of work, dependability, judgement, attitude, corporation and initiative.

5. Ranking whereby employees are put in sequence with respect to their performance. They are generally evaluated from the best to the worst.

6. Another factor as outlined by Schimdt et al., [21] is for both employees or teams and employer to enter into a collective target agreement mainly on performance objectives.

To put the spotlight on the above with Schimdt et al.'s opinion [21], employees' performance will display positive effects on motivation when they are involved in the designs of performance related systems or have positive relationship with their superiors. In addition, the human resource Management International Digest [23], drew an attention on performance appraisals to be based on customer focused employees, upon information derived from performance data bases.

\section{The Relationship between Performance Related Reward Systems and Work Performance}

Numerous studies found a positive relationship between performance related reward system and work performance [18] [24]. Westover, Westover and Westover [25], with reference to the equity model provides that, by nature, if an employee sees that another worker is compensated more or equal reward for doing less work, it will have an impact on his/her level of satisfaction in the workplace. It is therefore an employer's duty to see to it that there is fairness that will help employees to be treated equitably, as "crabby people make a crabby workplace where else, happy people make a happy workplace.” Moreover, Wiley [19], suggested that work performance and an engaged workforce are complementary for maximizing organisation success. Motivated employees tend to recommend their organisation as a good place, given a high level of satisfaction.

Tsai et al., [2] drew an attention on the hiring of better employees to work harder, efficiently and smarter to enhance work performance excellence. Levine as cited in Tsai, Chou and Chen [2] points out that an organisation that pay high wages attract not only qualified but competent and productive candidates that recognise the firm's ability to achieve its objectives, and thus contribute to the overall performance of the organisation, as spotted by Milkovich and Newman as cited in Tsai et al. be it profitability, increasing efficiency, lower costs by attracting competent applicants, decrease turnover, increase work efforts and reduce shirking.

Moreover, the Human Resource Management International Digest [23] provides that what companies should 
be doing is to recognise and reward their best employee, as the downturn that is at hand now is that talented employees matter most. A focus is to retain those talented and pivotal employees in order to preserve institutional memory. The Human Resource Management International Digest further suggests that unrewarded employees may seek greener pastures elsewhere when opportunity arises and this will leave organisations with a corporate version of "Alzheimer's” disease.

\section{Discussion}

Provided the aforementioned review, there is no doubt that performance related reward systems have significant contributions to work performance, and eventually organisational performance. Once there are proper evaluation techniques in place, performance will be fostered. It is thus the duty of every organisation to see to it that it opted for evaluation systems that will yield not only better but accurate and appropriate results. Rewards that are performance based will drive not only employees but also work groups, work teams, departments, committees to work toward achieving organisational goals. This implies that several team members will share information with no hesitation because they all have one goal, which is achieving desired objectives in return of better and improved rewards. To put this in a nutshell, performance-related reward systems are the "engine” that drives to excellence in the organisations. To put in context Yilmaz and Chatterjee, as cited in Ou and Wang [17] who spotted that rewards closely tied to key performance measures will force employees to perform above minimum expectations to maximise those performance measures and consequently maximise their pay level, a general conclusion to be drawn here is that rewards are key motivators to maximum performance. Employees will be forced to perform even in uncertain conditions such as inflation, recession, low peak seasons and so on, yielding results that will bail out organisations in those difficult times.

Moreover, the call of performance related rewards helps to solve grievances especially those of Workers' Union to Management, employer to employee, and vice versa with regard to compensations. With these systems in place, aggrieved parties will always be enabled to always refer to the score card and settle the differences, thus saving company time on negotiations, which in most cases don't benefit anyone other than unions.

\section{Conclusion}

The most fundamental benefit that employees seek in the workplace is satisfaction, while employers seek maximum work performance. However, for complementary results, the enforcement of a proper performance related reward system with proper evaluation measures must be put in place. Moreover, the study provides that there is a positive relationship between performances related rewards and work performance. This is sought through joint reward systems, monetary and non-monetary reward systems. In the light of the above, one can deduce that putting a proper performance related reward system in place is a silver bullet for any organisation to achieve its set goals, objectives, strategies, vision and mission.

\section{Acknowledgements}

All thanks to God, the Almighty who made everything possible throughout the carrying of this study. Sincere gratitude is owed to Dr. Rashad Yazdanifard, a co-author who has been driving the "study bus" to a successful journey. Without him, the study would have never been a success. Maximum thanks are also owed to OlajideBadmus who acted as a proof reader of this review. Lastly, but yet importantly, the researcher wish to thank all the previous researchers, whose data are referenced in this study. This is because, this study could have not been a complete success without their contributions.

\section{References}

[1] Lussier, R.N. (2009) Management Fundamentals: Concepts, Applications and Skill Development. South Western Cengage Learning, Mason.

[2] Tsai, K.H., Chou, C. and Chen, M.Y. (2008) Does Matching Pay Policy with Innovation Strategy Really Improve Firm Performance? An Examination of Technology-Based Service Firms. Personnel Review, 37, 300-316. http://dx.doi.org/10.1108/00483480810862288

[3] Tsun, J.C., Shang, P.Y. and I-Jan, Y. (2007) The Effects of Joint Reward System in New Product Development. International Journal of Manpower, 28, 276-297. http://dx.doi.org/10.1108/01437720710755254 
[4] Gross, R., Elhaynay, A., Friedman, N. and Buetow, S. (2008) Pay for Performance in Islaeli Sick Funds. Journal of Health and Management, 22, 23-35. http://dx.doi.org/10.1108/14777260810862380

[5] Barth, E., Bratsberg, B., Haegeland, T. and Raaum, O. (2008) Who Pays for Performance? International Journal of Manpower and Management, 29, 8-29. http://dx.doi.org/10.1108/01437720810861985

[6] Mason, W. and Watts, D.J. (2010) Financial Incentives and the Performance of Crowds. ACM SigKDD Explorations Newsletter, 11, 100-108. http://dx.doi.org/10.1145/1809400.1809422

[7] Zhou, Y., Zhang, Y. and Sánchez, A.M. (2011) Utilitarianism or Romanticism: The Effect of Rewards on Employees' Innovative Behaviour. International Journal of Manpower, 32, 81-98. http://dx.doi.org/10.1108/01437721111121242

[8] Canos-Daros, L. (2013) An Algorithm to Identify the Most Motivated Employees. Management Decision, 51, 813-823. http://dx.doi.org/10.1108/00251741311326581

[9] Irs, R. and Türk, K. (2012) Implementation of the Performance-Related Pay in the General Educational Schools of Estonia: Perspectives and Possibilities. Employee Relations, 34, 360-393. http://dx.doi.org/10.1108/01425451211236823

[10] Mao, N., Song, H. and Han, Y. (2013) High-Performance Work Systems and Influence Processes on Employees’ Attitudes: Perspectives from China. International Journal of Manpower, 34, 736-752. http://dx.doi.org/10.1108/IJM-07-2013-0157

[11] Crumpton, M.A. (2013) Keeping Motivation Going. The Bottom Line: Managing Library Finances, 26, 144-146. http://dx.doi.org/10.1108/BL-10-2013-0029

[12] Markova, G. and Ford, C. (2011) Is Money the Panacea? Rewards for Knowledge Workers. International Journal of Productivity and Performance Management, 60, 813-823. http://dx.doi.org/10.1108/17410401111182206

[13] Rack, O., Ellwart, T., Hertel, G. and Konradt, U. (2011) Team Based Rewards in Computer-Mediated Groups. Journal of Managerial Psychology, 26, 419-438. http://dx.doi.org/10.1108/02683941111139029

[14] Bamberger, P.A. and Levi, R. (2009) Team-Based Reward Allocation Structures and the Helping Behaviours of Outcome Independent Team Members. Journal of Managerial Psychology, 24, 300-327. http://dx.doi.org/10.1108/02683940910952705

[15] Babtiste, N.R. (2008) Tightening the Link between Employee Wellbeing and Performance: A New Dimension for HRM. Management Decision, 46, 284-309. http://dx.doi.org/10.1108/00251740810854168

[16] Koopmans, L., Bernards, C.M., Hilderbrandt, V.H., Schaufeli, W.B., De Vet, H.C.W. and Der Beek, A.J. (2011) Conceptual Frameworks of Individual Work Performance: A Systematic Review. Journal of Occupational and Environmental Medicine, 53, 856-866.

[17] Ou, W.M. and Wang, H.D. (2009) The Influence of Controllability on Compensation: A View through Data of Major League Baseball. International Journal of Commerce and Management, 19, 321-336. http://dx.doi.org/10.1108/10569210911008494

[18] Silveira, G.J.C., Snider, B. and Balakrishnan, J. (2013) Compensation-Based Incentives, ERP and Delivery Performance: Analysis from Production and Improvement Perspectives. International Journal of Operation and Production Management, 33, 415-441. http://dx.doi.org/10.1108/01443571311307307

[19] Wiley, J.W. (2010) Driving Success through Performance Excellence and Employee Engagement. http://www.kenexa.com/getattachment/c7f8d19b-671d-4873-a580-339e25c11640/Driving-SuccessThrough-Performan ce-Excellence-and.aspx

[20] Becton, J.B., Giles, W.F. and Schrader, M. (2008) Evaluating and Rewarding OCBs: Potential Consequences of Formally Incorporating Organisational Citizenship Behaviour Performance Appraisal and Reward Systems. Employee relations, 30, 494-514. http://dx.doi.org/10.1108/01425450810888277

[21] Schmidt, W., Trittel, N. and Müller, A. (2011) Performance-Related Pay in German Public Services: The Example of Local Authorities in North Rhine-Westphalia. Employee Relations, 33, 140-158. http://dx.doi.org/10.1108/01425451111096686

[22] Prowse, P. and Prowse, J. (2009) The Dilemma of Performance Appraisal. Measuring Business Excellence, 13, 69-77. http://dx.doi.org/10.1108/13683040911006800

[23] Human Resource Management International Digest (2010) Keeping the Top Talents on Board: Retaining the Best Is as Good as Retaining Them. 18, 20-32.

[24] Wiley, J.W. (2012) Giving Employees What They Want Can Provide Employers with What They Want. Employment Relations Today, 39, 45-53. http://dx.doi.org/10.1002/ert.21354

[25] Westover, J.H., Westover, A.R. and Westover, L.A. (2010) Enhancing Long-Term Worker Productivity and Performance: The Connection of Key Work Domains to Job Satisfaction and Organizational Commitment. International Journal of Productivity and Performance Management, 59, 372-387. http://dx.doi.org/10.1108/17410401011038919 
Scientific Research Publishing (SCIRP) is one of the largest Open Access journal publishers. It is currently publishing more than 200 open access, online, peer-reviewed journals covering a wide range of academic disciplines. SCIRP serves the worldwide academic communities and contributes to the progress and application of science with its publication.

Other selected journals from SCIRP are listed as below. Submit your manuscript to us via either submit@scirp.org or Online Submission Portal.
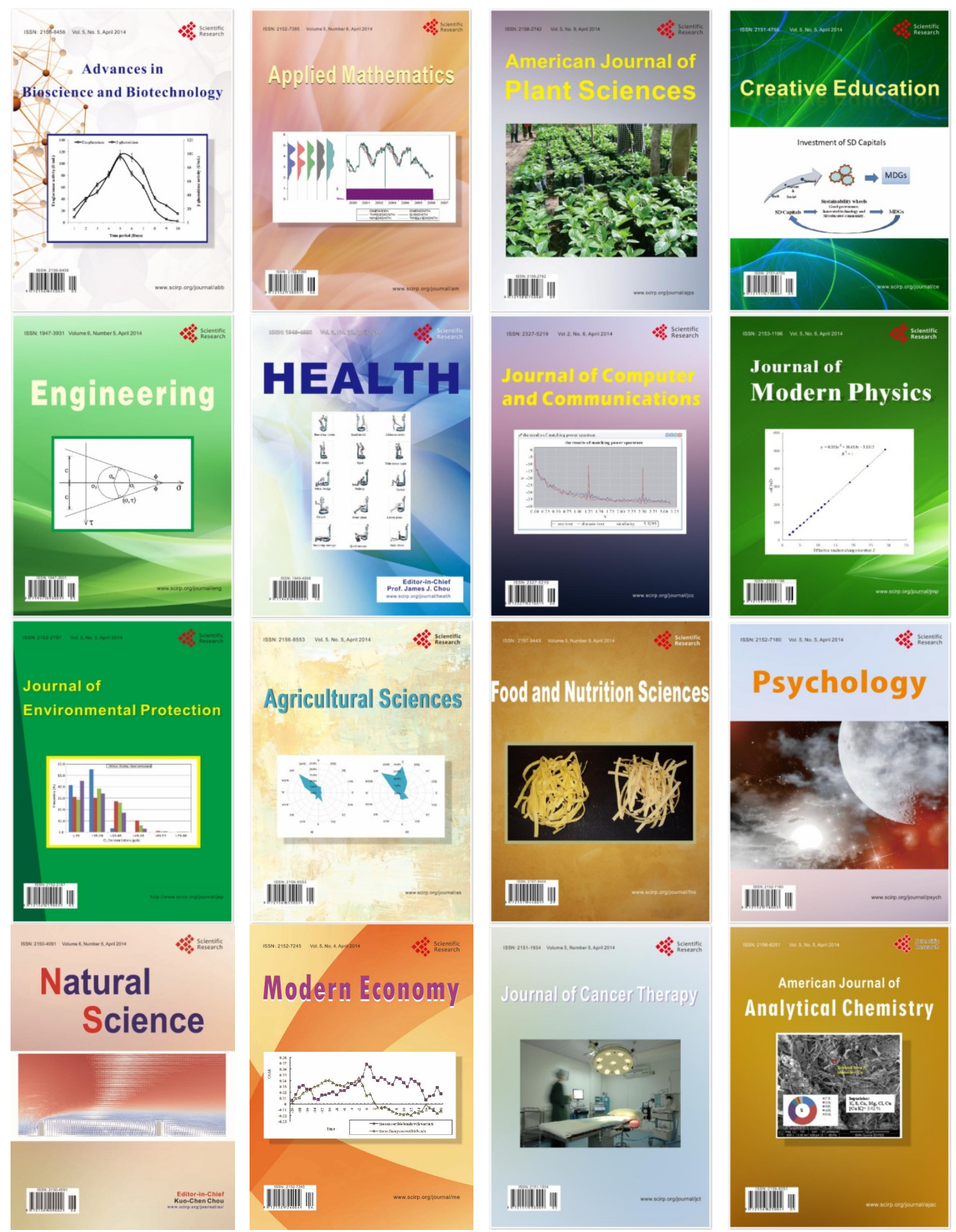